\title{
Foreign Exchange and U.S. Balance-of-Payments Developments in 1972 and Early 1973
}

\author{
by CHRISTOPHER L. BACH
}

T HE MAGNITUDE of the U.S. balance-of-payments deficit and concern about the effective operation of the international monetary system dominated thinking about U.S. payments problems and policies in 1972. The same concerns had been paramount in 1971. The overall U.S. deficit during 1972 was reduced to $\$ 10.3$ billion from $\$ 29.8$ billion in 1971 as net shortterm capital outflows subsided. But many of the same intemational monetary problems were present in both years, in spite of a multilateral agreement in December 1971 to devalue the dollar, realign other parity values, and widen the permissible range of exchange rate fluctuation.

The basic problem for the intemational monetary system was the same in 1972 as in 1971. The system could not promote effective balance-of-payments adjustment, given the conflicting policy objectives of fixed parity rates and the pursuit of independent domestic stabilization policies. The conflict became more intense as the integration of national economies and capital markets continued. Thus, persistent payments surpluses and deficits continued, thereby creating a gap between the official international values of currencies and their domestic values.

While the long-run problem for the intemational monetary system was lack of balance-of-payments adjustment, the short-run problem in both years was controlling the large scale intemational capital flows that were generated by the increased awareness that prevailing parity rates were inappropriate. To stem these flows, at a time when inflationary pressures were still present, most major nations instituted controls on banks and other financial institutions. However, as these actions proved insufficient, several countries adopted some form of flexible exchange rate ${ }^{1}$

\footnotetext{
Tharge scale capital flows were most evident from late June to early July 1972 and from January to early March 1973. However, over the remainder of the fifteen-month period under discussion, capital flows were significantly smaller than in 1971. The reduction in capital flows largely reffected the more realistic set of exchange rates that had been adopted at the end of 1971 .
}

As 1972 ended, only minor progress had been made toward basic changes in the international monetary system. In addition, sufficiently rapid progress toward further reduction in the overall U.S. payments deficit. in 1973 seemed, to some observers, to be problematical at best. Given this outlook, and pressured by the unprecedented capital movements associated with the monetary crisis of late January and February 1973, the United States moved further early this year to carry forward its policy of reducing the U.S. payments deficit. The program announced by Treasury Secretary Shultz on February 12 included not only a ten percent devaluation of the dollar, but also proposals for comprehensive trade legislation, and a decision to phase out U.S. direct controls on capital movements by the end of 1974 . These moves reflected the Ad ministration's belief that the best path toward a viable international monetary system, and trade and payments equilibrium, was through a more competitive market environment with appropriate parity rates - not through controls and restrictions on international exchange.

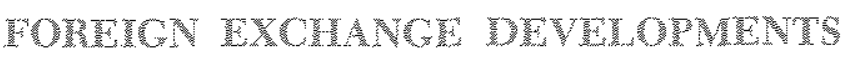

The major foreign exchange developments in 1972 and early 1973 can be divided into three time periods: the period preceding the sterling crisis of late June and early July; the period during the sterling crisis until the close of 1972; and the period of international monetary turmoil in early 1973.

\section{Prior to the Shenting Crists}

Following the Smithsonian agreement of December 1971, exchange rates of most major nations settled near the floor of their newly prescribed ranges, but moved rapidly upward in the first two months of 1972. During this period, there was considerable concern over the viability of the new set of parity rates. The greatest uncertainty arose because of the fear that some countries might not maintain the convertibility of their currencies at the limits set by the Smithsonian 


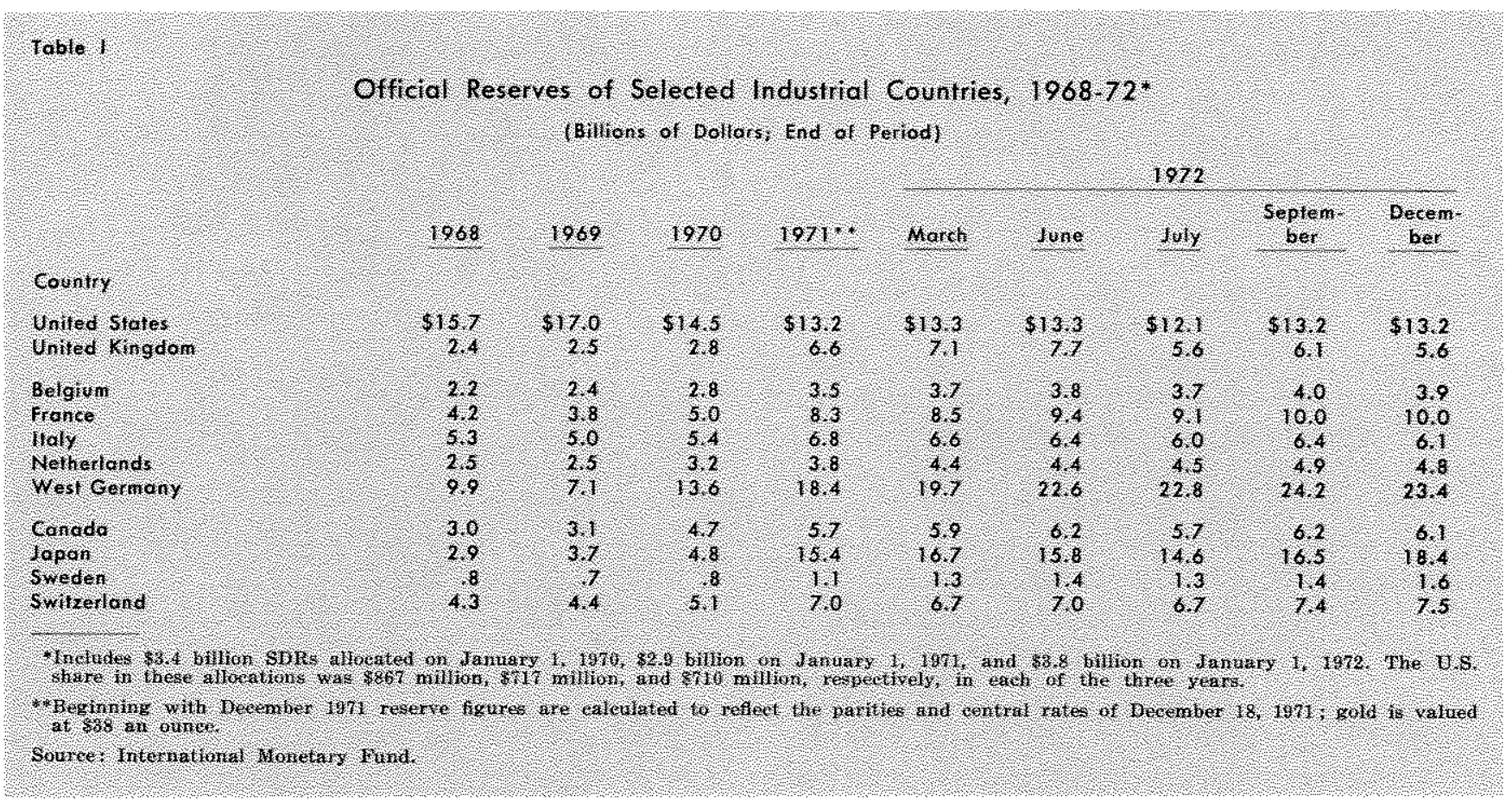

agreement. Several central banks intervened in their respective foreign exchange markets as their currencies approached their ceilings relative to the dollar. These actions were necessary to stem successive periods of foreign exchange pressure on the mark, guilder, Belgian franc, and the yen. The net conversion of dollar assets into assets denominated in other currencies continued, but at a much lower rate than in the second half of 1971.

From mid-March to early June there was relative calm in the foreign exchange markets. Early in the period European authorities and U.S. officials reaffirmed their confidence in the new exchange rate relationships and the United States pledged that monetary policy would not become too stimulative. Major European currencies backed away from their ceilings relative to the dollar in late March and April. The Germans moved to strengthen capital controls by further restricting borrowing abroad by German corporations, and the Japanese reinstated controls on nonresident purchases of yen. Discount rate cuts were announced in Germany, Belgium, and the Netherlands to encourage domestic growth and discourage large capital inflows. U.S. short-term interest rates began to rise sharply, and total capital outflows from the United States temporarily abated.

On May 1 the United Kingdom joined with its prospective Common Market partners in an agreement to narrow the spread between sterling and any other Common Market currency to no more than $2 \%$ percent. $^{2}$ The European Community (EC) monetary agreement thus created a double system of exchange rate limits, in which the $2 \%$ percent $\mathrm{EC}$ band (referred to as the "snake") was entirely contained, and free to move, within the larger $4 / 2$ percent Smithsonian band (referred to as the "tunnel"), A critical feature of the European Community agreement was that intervention in dollars was to be confined to situations in which an EC currency declined or rose to the full limits of its Smithsonian floor or ceiling. Otherwise, maintenance of currency convertibility at the $2 *$ percent band was to be carried out by inter. vening in each other's currencies.

\section{The Stering Criss and Afers}

The period of relative exchange market calm and temporary European experimentation with a narrowed exchange rate band came to an abrupt halt in midJune. Downward speculative pressures on sterling resulted in a decision by U.K. officials to cease intervening in the foreign exchange market and to permit the exchange rate to be determined by market forces. Thus, on June 23, after six days and an expenditure of $\$ 2.6$ billion, the British authorities suspended their participation in the Smithsonian and EC currency arrangements. On June 26, Denmark also temporarily

"The original announcement by the European Community (EC) countries of their intention to narrow the margin of fluctuation among their own currencies to $2 y$ percent was made on March 7 . The arrangement came into operation anong the original EC eurrencies on April 24. 
withdrew from the EC monetary agreement, while Italy secured temporary authorization to keep the lira within the $2 \frac{1}{4}$ percent $\mathrm{EC}$ band by intervening in dollars rather than in European currencies.

Throughout the period, speculative attention tumed toward the dollar amid concem that either the Smithsonian or EC rate structures and commitments would be abandoned, and that European currencies would move upward relative to the dollar, either singly or jointly. In order to reduce large capital inflows, Switzerland and Germany imposed additional restrictions on foreign transfers of funds into their currencies. Even so, flows into the strong European currencies and the yen continued. From June 15 to July 14, the sterling crisis resulted in major countries other than the United Kingdom acquiring $\$ 6$ billion as they absorbed dollars in exchange for their own currencies.

As its part in calming the summer speculative crises, the United States renewed limited operations in the foreign exchange markets which it had suspended on August 15, 1971. On July 19, 1972, the Federal Reserve System, in cooperation with the Bundesbank, initiated several sizable operations in German marks in the New York market. On August 10, the System initiated similar action for the Belgian franc. In total, the Federal Reserve intervened in the market on nine occasions between July 19 and September 1 , and in the process sold $\$ 31.5$ million of foreign currencies.

In the last quarter of the year, foreign exchange market pressures arising from capital flows subsided, and the EC exchange rates moved down from their ceiling rates relative to the dollar. Some dollar balances were transferred back to the United States as a result of the strong recovery in the U.S. economy and progress that had been made in the fight against inflation. At the close of the year, the effective tradeweighted devaluation of the dollar vis-á-vis eleven major countries amounted to just over 10 percent from pre-June 1970 parities, or about the same level as at the end of January 1972.

Pressures on the Japanese yen intensified during the last half of the year, reflecting the continued sizable surplus in the Japanese balance of payments. The Japanese surplus position was accentuated by the relative cyclical positions of major nations. Japanese exports to the United States rose especially sharply as the U.S recovery progressed. Japanese imports also rose at a rapid rate in 1972 , but the increase was insufficient to offset the rise in exports. Throughout the period, Japanese authorities purchased large amounts of dollars in the foreign exchange markets to

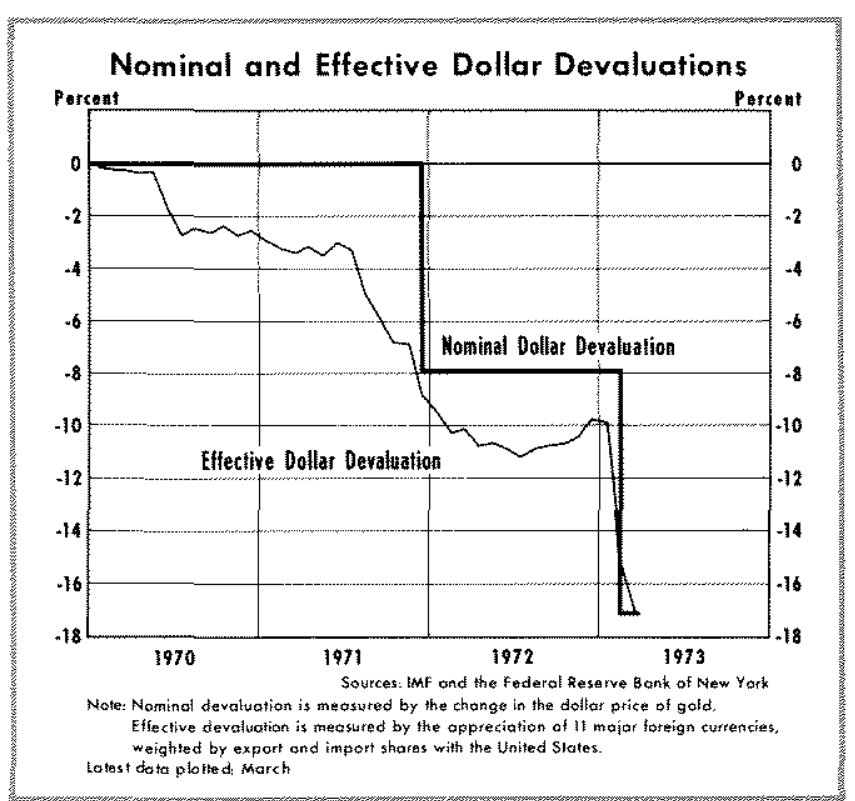

keep the value of the yen from rising above its Smithsonian ceiling. Forward yen rates remained substantially above the Smithsonian ceiling reflecting market expectations of a further revaluation of the yen.

\section{Krats 1079}

The capital flows which led to the dollar devaluation on February 12, 1973 were of record proportions. In the closing days of January and the first nine days of February, about $\$ 9$ billion was accumulated by central banks in strong currency countries. Germany acquired more than $\$ 6$ billion, Japan about $\$ 1.5$ billion, and other countries about $\$ 1.5$ billion.

U.S. liabilities to foreign central banks and official agencies increased by nearly $\$ 9$ billion in the first three weeks of February, as dollars were transferred from private to official foreigners. Direct outflows of dollars from the United States apparently covered a broad spectrum of transactions, including leads and lags in trade and other international payments, portfolio shifts, and foreign borrowing from the United States.

The immediate reaction to the U.S. devaluation and statement on trade and financial policy on February 12 was a brief abatement of large scale capital flows. Countries which had previously established capital controls retained them until they found out how viable the new exchange rate relationships would be. Japan, as part of the agreement to reduce currency speculation, permitted the yen to float relative to other currencies. France and Germany retained the same parity value relative to each other and both effectively ap- 
preciated ten percent against the dollar. The United Kingdom maintained the flexible exchange rate policy it had established during the sterling crisis in the summer of 1972 . However, the U.S. devaluation did not succeed in restoring confidence in dollar parity rates, and amid talk of a joint EC float, the dollar was again heavily sold and official currency markets were closed on March 2. They remained closed until March 19.

Short-term arrangements to control capital flows which were agreed upon during the week of March 12, resulted in a joint float against the dollar by some European currencies. ${ }^{3}$ As part of the agreement, Germany announced an additional three percent revaluation of the mark. Japan, Italy, and the United Kingdom elected to allow their currencies to float against all currencies.

\section{PA}

The overall balance-of-payments deficit of the United States, while still far from balance, diminished sharply in 1972. The official settlements deficit declined from $\$ 29.8$ billion in 1971 to $\$ 10.3$ billion in 1972. The improvement of 1972 over 1971 occurred in the capital accounts. Most of it consisted of a reduction in short-term capital outflows. But in addition, there was a marked reduction of U.S. direct investment abroad. By contrast, trade and current account deficits were considerably larger than in earlier years.

\section{Current kecoum}

The trade account, which is the largest component of the current account, increased from a $\$ 2.7$ billion deficit in 1971 to a $\$ 6.8$ billion deficit in 1972 . The deterioration can generally be attributed to (1) the relative income, output, and price trends in major industrial nations and the United States, and (2) the initial impacts of the parity rate adjustments made in December 1971. Both factors are discussed below.

As a general rule, movements of U.S. nonagricultural exports are related to income, output, and price movements in other industrial nations relative to those in the United States. The accompanying chart shows the total effect of these movements, and indicates the cyclical nature of U.S. exports. The rate of expansion in foreign industrial production varied between five and ten percent over the decade, and resulted in

3The European comntries currently participating in the joint float are Germany, France, the Netherlands, Belgium, Luxemburg, Denmark, Norway and Sweden.

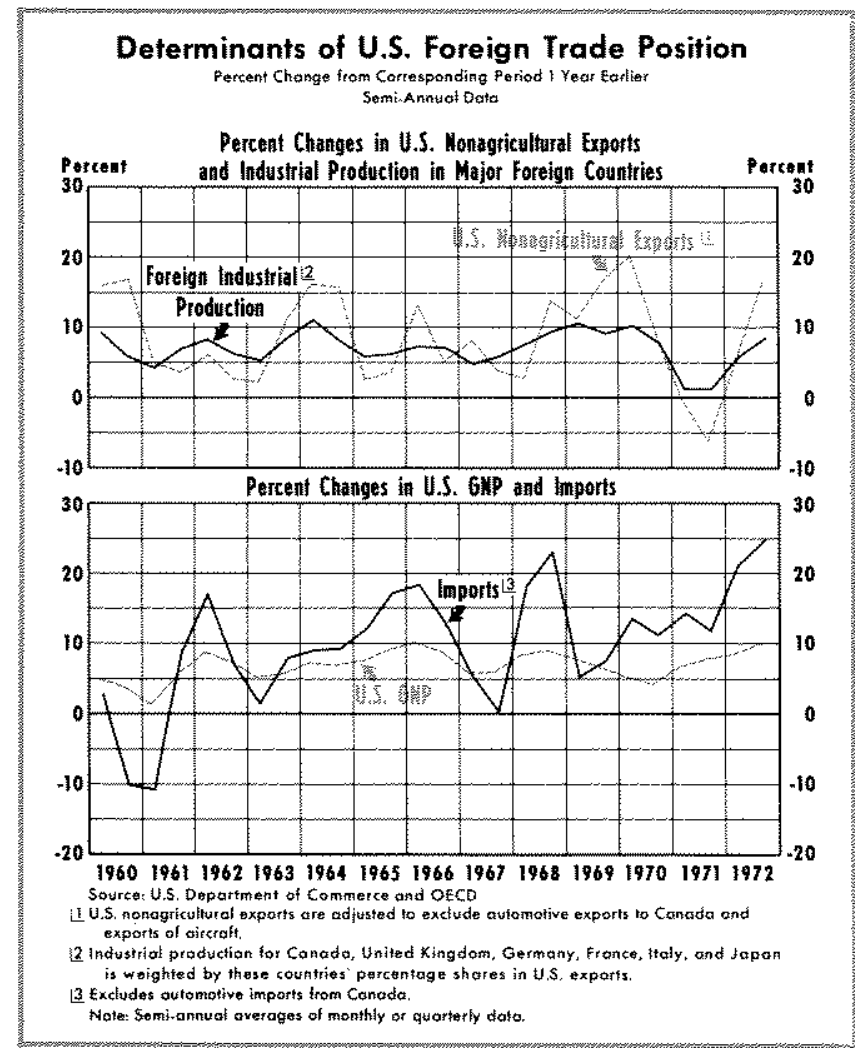

wider and nearly simultaneous fluctuations in U.S. export growth. An increase in the rate of expansion of foreign industrial production in 1967 and 1968 was followed by a rise in U.S. export growth, and a subsequent decline in the rate of expansion of foreign industrial production in 1970-71 was followed by a decrease in U.S. export growth. U.S. export growth rose sharply in 1972, in line with renewed business expansion in most major nations and improved price performance in the United States relative to its major trading partners.

Movements in U.S. imports are primarily related to changes in total demand for goods and services in the United States. U.S. imports are also cyclical in their response to domestic output and price pressures. Variations in U.S. GNP growth over the past decade were accompanied by simultaneous, but wider, fluctuations in import growth. The business expansion in the United States was accompanied by a sharp rise in imports in 1972, even though domestic inflationary pressures in other major countries were greater than in the United States.

Analysis of the U.S. trade balance in 1972 must also account for the impact of the parity rate realignment of December 1971. An objective of the realignment as far as the United States was concerned was to raise the dollar price of its imports and lower 
the foreign currency price of its exports. These factors were expected to lead ultimately to an increase in the rate of growth of export volume and a decrease in the rate of growth of import volume.

The extent to which the U.S. trade position will be affected by the devaluation depends upon the responsiveness of the growth in volume of exports and imports to relative price changes. Imports which are relatively insensitive to price changes, such as fuels and lubricants, would be expected to increase in total dollar value because the dollar price of U.S. imports would be raised while the growth of import volume would be little changed from previous growth patterns. For imports which are relatively sensitive to price changes, such as semi-manufactured materials and consumer products, the rise in dollar prices would be accompanied by a relatively greater decline in the growth of import volume. The same principles would be expected to hold for price and volume relationships of exports. Increased growth in export volume would be expected for those goods which are relatively sensitive to price changes, such as finished manufactures, as a result of the decline in foreign currency prices of U.S. exports.

Another issue concerning the impact of the devaluation on the U.S. trade position is how long it will take to achieve complete adjustment to the new set of parity rates. The adjustment process is likely to be rather lengthy because producers in both devaluing and revaluing countries may respond not only by immediately changing prices offered to buyers, but by altering investment, production, and marketing plans as profit positions change over the intermediate or long run. Only when these basic management decisions have been made and implemented will there be a marked change in the quantities supplied, or a shift in the destination of exports. The same producer decisions will affect the length of time it takes to significantly alter quantities of imports. ${ }^{4}$

¿Econometric evidence regarding demand and supply price elasticities in foreign trade provides a wide range of different results, even for indtwidual countries. Moreover, it could be doubted whether elasticities calculated over an observation period in which year-to-year changes in relative prices were typically small and, for a number of contries, predominantly in one direction, would necessarily be applicable to a large discrete change, particularly one which went in the opposite direction to the previous persistent movement. A further complication is that despite the widely held view that parity changes take two years or more to work through in full, econonetric evidence of lags of this length is weak or nonexistent.

An equally difficult problem is the assessment of the changes in relative prices to which price elasticities should be applied. There was no previous experience that indicated how international traders wotld adiust prices following a general realignment of currencies. There was a presmmption that countries with little or no change in their effective exchange
In the interim, the initial impact of the dollar devaluation on the U.S trade balance in 1972 was to raise the dollar price of imports with relatively little short-run response in volume to the price changes. U.S. export volume may have responded slightly to the lower foreign currency prices of U.S. goods. Over the course of the year, there was probably little net effect of the new parity rates on the trade balance. The trade deficit increased in the first four months of 1972 , and diminished slowly, on balance, during the last eight months.

The invisibles balance, another major component of the current account consisting primarily of net investment income and service transactions, rose to a $\$ 1.2$ billion deficit in 1972 from near balance in 1971 . The deterioration may have been due, in part, to the cyclical upswing in the United States. There had been hope that the invisibles balance might shift to a surplus in 1972 because of a substantial rise in U.S. companies' earnings abroad and the favorable effect of the dollar devaluation on the dollar equivalent of earnings converted from foreign currencies. However, the repatriated income from U.S. direct and other overseas investments was largely offset by the sharp rise in income paid to foreigners on their investments in the United States. Much of the income payment took the form of interest paid on U.S. Government securities which had been acquired mainly by foreign central banks as a result of past U.S. payments deficits and recent international currency crises.

\section{Long-rad Shownerm Captul}

Several fundamental factors were responsible for the sharp reduction of both long- and short-term net capital outflows in 1972 over 1971 . First, the realignment of parity rates and continued international cooperation among major nations helped to reestablish confidence in international financial relationships. With the exception of the June-July period and the January-March 1973 crisis, investors had less incentive

rate would show little or no change in export prices (compared to what they otherwise would have been), expressed in their own local currencies. Likewise, there was a presumption that countries undergoing effective devaluation (revaluation) would be expected to raise (lower) their local currency export prices, to an extent that would depend, among other things, on exporters profit margins and the import content of exports. A source of complication was that, in the past, there seemed to have been a tendency for exporters in other comtries to treat the United States as a separate market for purposes of price setting. Consequently, they tended to gear their dollar prices in the United States to U.S. domestic prices. For most other countries, import prices appeared to be largely determined by the general level of other countries' export prices.

For a further discussion of these points as they apply to particular countries, see the analysis of the parity rate realignment in OECD, Economic Outlook (July 1972). 
Table il:

U.S. Balance of Payments, 1960,72

(billons of dollowe?

Type of Tronsodion

Merthondlse lrede bolonce

Export:

Inports

Mitiory toroochors, net

Boltrice on invertient heone

US. Anvestinent ob tood

foreigh thvetinent in the Uhiled States

Bolonce on ollet services

BALANCE ON GOODS AND SERVICES

Rivote remillances ond governitert persions

BALANCE ON GOODS, SERVICE, AND REMITALCES

Government Gronts?

\section{BALANCE ON CURRENT ACCOUNT}

Bolance on dited privale invertment

US dired thvestment abroud

forolgh dired nuestmen in the United Stots

Bolonce on other long term capilal frowet

BALANCE ON CURRENT ACCOUNT AND

LONG-TERM CAPITAL

Bolonce on Honliguld short tern privale apilo fows

Erow and untecorded hansoctions

Allorolion of sperid draweng rights

NET LOUDDTY BALANCE

Transactions in US, liguid thoit term assers nel

Transactions in U.S. Iq Gid liabilities to ot her that foreign officiol agencies, ner

OFICIAL GESERU TRANSACTIONS OALANCE

Financed by changes in:

Nonllaut U,S Govenment ond US, benk liablithe

10 foreten offitiol agencies 6

liquid liabalines to torigh officiol agencies

U.S officiol ther we ostels, net

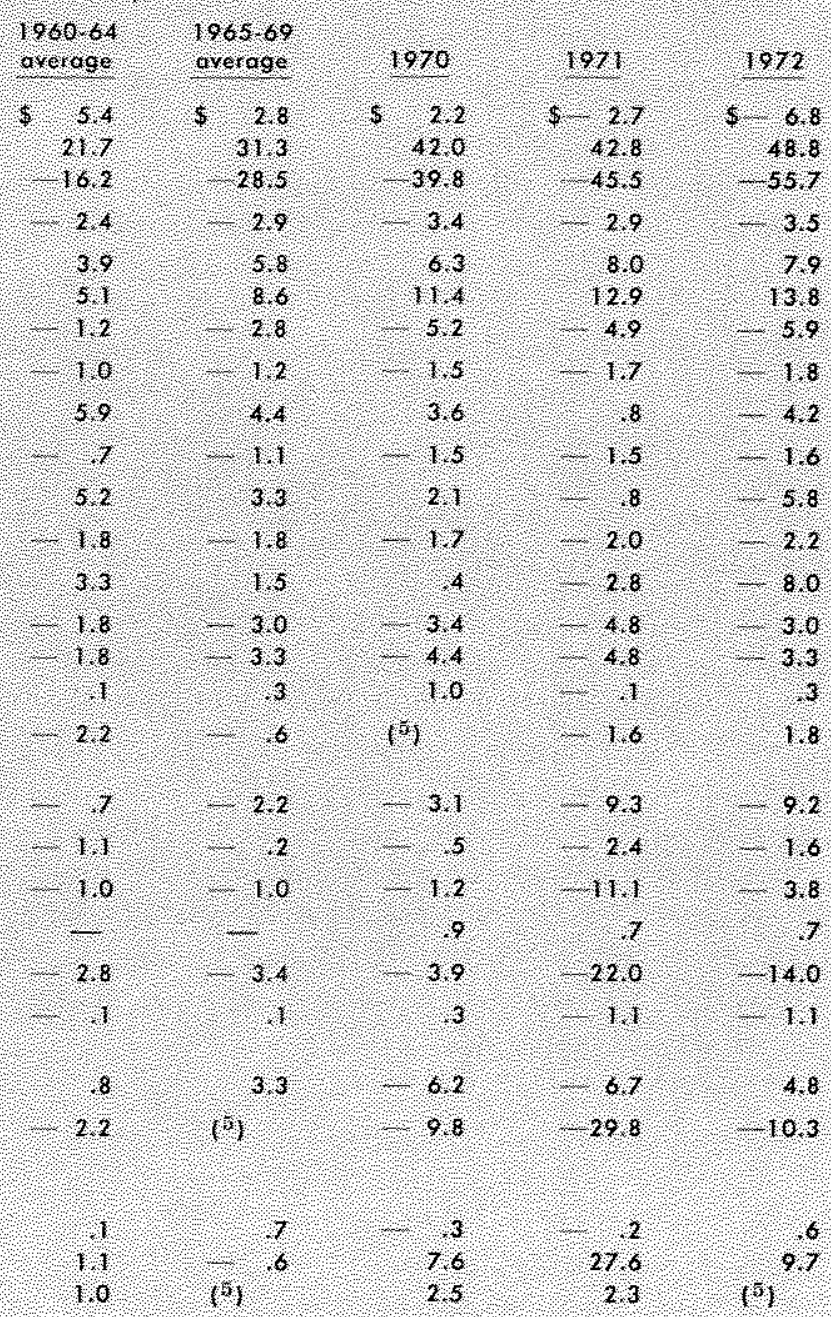

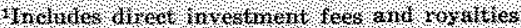

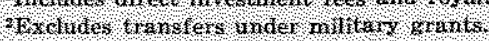

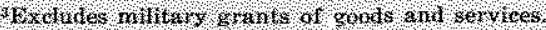

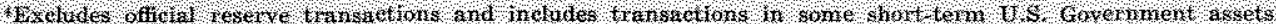

1 ess then $30,0,1110 \mathrm{n}$

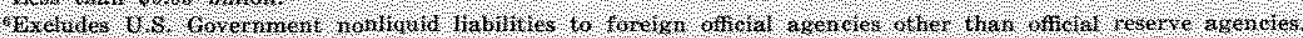

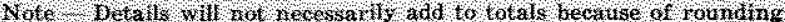

Sontee loepartunent of Commeres

to hedge against possible changes in parity rates and some funds returned to the United States. Continued questioning of the parity values of the mark and the yen may have prevented even greater dollar reflows. Second, over the course of the year, rising interest rates in the United States relative to those in Europe led to a reversal of some interest-sensitive funds. Third, the rapid expansion of the U.S. economy compared to other major foreign countries created an improved investment outlook in the United States and reduced incentives for investments in other countries.
Net long-term capital outflows in 1972 diminished sharply from $\$ 6.5$ billion in 1971 to $\$ 1.3$ billion in 1972. This was in contrast to the developments on the trade and current accounts. Almost eighty percent of the $\$ 5.2$ billion reduction was due to the sharp cutback in capital outflows by U.S. corporations. In part, this occurred because corporations increased their long-term borrowing abroad by over $\$ 1$ billion. The reduced net private capital outflows also reflected slack capacity utilization in Europe. Since some countries were still in periods of slow growth or 
recession, there was considerably less demand by foreign affiliates for plant and equipment expenditures in 1972 compared to 1970 and 1971. Another factor responsible for reducing net long term private capital outflows was the significant increase in net foreign purchases of U.S. securities. Foreign direct investment in the United States also increased.

Short-term capital outflows also diminished sharply from the previous year. Certain nonliquid short-term private capital outllows (mainly loans by banks and nonbanks to finance foreign trade) diminished from $\$ 2.4$ billion in 1971 to $\$ 1.6$ billion in 1972 . Because some speculative capital flows may have been registered in this account last year, it is not possible to determine how much of the reduction represents a change in trend and how much a reduction in speculative capital flows.

Errors and omissions (items not recorded in any of the above accounts but generally thought to be un recorded capital flows) also diminished sharply in 1972 from 1971 . The net outflow was $\$ 3.8$ billion in 1972 compared with $\$ 11.1$ billion in 1971. A shift in interest rate pattems over the course of the year and temporary abatement of concem about the exchange rate structure in most months were probably the fundamental factors contributing to improvement in this account.

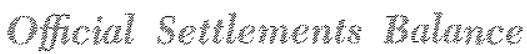

The official settlements balance registered a $\$ 10.3$ billion deficit in 1972 , compared to a $\$ 29.8$ billion deficit in 1971 and a $\$ 9.8$ billion deficit in 1970 . In addition to the factors mentioned above, net liquid private capital outflows (mainly short-term assets and liabilities transferred among U.S. and foreign commercial banks) diminished in 1972, and thereby also contributed to the reduction in the official settlements deffeit. Net liquid private capital flows shifted from outflows of $\$ 6$ billion and $\$ 7.8$ billion in 1970 and 1971, respectively, to a net inflow of $\$ 3.7$ billion in 1972. As in 1970 and most of 1971, liquid private capital movements in 1972 were sensitive to domestic and Eurodollar interest rate differentials, and in some periods, to anticipated changes in the parity values of the dollar relative to other major currencies. The official settlements balance was financed in 1972 almost entirely by an increase in liquid liabilities to foreign official agencies.

\section{SUMWMUN}

The reduction of the U.S. official settlements deficit in 1972 over 1971 was composed of two diverse trends. The trade and current account deficits were considerably larger than in earlier years due primarily to the relative cyclical positions of major nations. The effects of the dollar devaluation of December 1971 probably had little net impact on these deficits over the course of the year, By contrast, the capital account deficit diminished markedly because of the reduction in longand short-term capital outflows over most of the year. However, the sterling crisis of mid-1972 and the currency speculation in early 1973 resulted in renewed sizable outflows on capital account.

Although monetary officials devoted considerable attention in 1972 to considering alternative solutions to the long-run adjustment problem of the international monetary system, foreign exchange market pressures forced them to focus even more of their attention on controlling large, primarily short-term, capital flows. Lack of concensus as to the most effective means to control these flows, and in some cases lack of sufficient governmental cooperation to achieve the most desired results, led many nations to establish numerous foreign exchange controts and to allow their exchange rates to be at least partially determined by market forces.



Page 20 